\title{
DE (DIS)CONTINUÏTEIT VAN DE ONDERNEMING EN DE TOELICHTING OP DE BALANS
}

\author{
door Mr. C. Kager
}

\section{Gevolgen faillissement en surséance}

In de faillissementswet worden geregeld zowel het faillissement als de surséance van betaling.

Door de failliet-verklaring verliest de schuldenaar van rechtswege de beschikking en het beheer over zijn tot het faillissement behorend vermogen, terwijl gedurende een surséance de schuldenaar onbevoegd is enige daad van beheer of beschikking betreffende de boedel te verrichten, zonder medewerking, machtiging of bijstand van de bewindvoerder(s).

In geval van faillissement rust op de curator de verplichting tot publicatie in de Nederlandse Staatscourant en in de door de rechter commissaris aange. wezen nieuwsbladen; in geval van surséance rust deze verplichting op de griffier der rechtbank.

Het blijkt in de praktijk dat deze beide ernstige gevolgen van het faillissement en de surséance van betaling . verlies van bevoegdheid tot beheer en be. schikken, alsmede de publicatie - er toe leiden, dat de bestuurders van onder. nemingen welke in moeilijkheden geraken, te laat reageren, waardoor red. ding niet of nauwelijks meer mogelijk is.

\section{Invoering meldingsplicht}

In het Nederlands Juristenblad van oktober 1978 heb ik gepleit voor de invoe. ring bij de wet van een vóórfase, door middel van een meldingsplicht door de onderneming, in welke vóór-fase geen bestuursbevoegdheden worden ontnomen en geen publicaties plaats vinden.

Het bestuur der onderneming wordt - in mijn voorstel - verplicht gesteld on der overlegging van recente bedrijfs- en resultaatgegevens zich te wenden tot de rechtbank van de plaats van vestiging, zodra het nakomen door de onder. neming van haar verplichtingen binnen afzienbare tijd moeilijkheden dreigt op te leveren.

De rechtbank benoemt een rapporteur die een onderzoek instelt naar de (dis)continuiteit van de onderneming. De rechtbank kan faillissement uitspreken of surséance verlenen op grond van de bevindingen van de rapporteur. Belangrijk is dat dit onderzoek in stilte zonder publiciteit plaats vindt.

Het onderzoek van de rapporteur kan leiden tot nieuwe contacten met aandeelhouders, bankiers, werknemers, crediteuren, klanten, overheid. 


\section{Tijdstip meldingsplicht}

Beslissend voor het functioneren van voorgeschreven meldingsplicht is uiteraard het tijdstip waarop deze verplichting intreedt.

De meldingsplicht welke berust bij het bestuur der onderneming, ontstaat op het moment dat de continuiteit van de onderneming wordt bedreigd, met andere woorden, zodra het moment nadert waarop de onderneming niet meer in staat is aangegane verplichtingen na te komen. Om dat moment te bepalen zou aansluiting kunnen worden gezocht bij een door het Nivra uitge. geven Meningsuiting van het college voor beroepsvraagstukken betreffende de inhoud van de accountantsverklaring bij de jaarrekening van ondernemin. gen met continuïteitsproblemen.

\section{Relatie waarderingsgrondslagen en tijdstip meldingsplicht}

In de meningsuiting wordt de vraag behandeld of waarderingsgrondslagen op continuitteitsbasis nog toepasselijk zijn indien onzekerheid bestaat omtrent de continuïteit van de onderneming.

Het is duidelijk - en dat wordt ook in de meningsuiting gezegd - dat in be ginsel de continuïteit van een onderneming nimmer geheel is gewaarborgd.

Het antwoord op de vraag of onzekerheid omtrent de continuiteit ontstaat wordt in de meningsuiting gezocht in de positie van belanghebbenden bij de onderneming, zonder de medewerking van dewelke de onderneming haar functies niet kan uitoefenen, zoals daar zijn (ik citeer): verschaffers van:

risicodragend vermogen

lang vreemd vermogen

kort vreemd vermogen

arbeid

goederen en diensten,

vaak gepaard met krediet

afzetmogelijkheden

en in verschillende rollen
aandeelhouders
obligatiehouders,
leningverstrekkers
bankier
werknemers

leveranciers

afnemers

de overheid

\section{v. Ernstige onzekerheid omtrent de continuïteit}

Het kritische moment, waarop de situatie intreedt, welke in de meningsuiting wordt aangeduid met: „ernstige onzekerheid omtrent de continuiteit”, is dat, waarop redelijkerwijs vaststaat dat de onderneming niet op eigen kracht haar verplichtingen zal kunnen nakomen; de meningsuiting omschrijft deze situatie als volgt „die waarin discontinuiteit onvermijdelijk is te achten zonder medewerking van belanghebbenden die verder gaat dan waartoe zij zich tot dusverre hebben verbonden, terwijl nog niet vaststaat of deze verdergaande medewerking zal worden verkregen".

De situatie van ernstige onzekerheid eindigt - aldus de meningsuiting · door de besluiten van belanghebbenden. 
Drie fasen $+0-$

Vóór en na de hier omschreven situatie van „ernstige onzekerheid omtrent de continuïteit" (aangeduid met het cijfer 0 in de meningsuiting), onderscheidt de meningsuiting een fase, waarin tenminste enige aanwijzing is dat het voortbestaan van de onderneming wordt bedreigd, maar waarin met als realistisch te beoordelen initiatieven nog een keer ten goede bereikbaar lijkt (aangeduid met het + teken), terwijl de derde fase de situatie bevat waarin belanghebben. den hun medewerking hebben opgezegd. (aangeduid met het - teken).

In de meningsuiting wordt deze derde fase als volgt omschreven: belangheb. benden zeggen hun medewerking op ,en zullen waarschijnlijk niet vervangen kunnen worden".

Ik kan niet beoordelen in hoeverre deze laatste zinsnede van belang is voor het antwoord op de vraag welke waarderingen in de jaarrekening op conti. nuiteitsbasis of op liquidatiebasis geschieden, maar wanneer ik bij de omschrij. ving van de drie genoemde fasen aansluiting ga zoeken voor de bepaling van het moment, waarop de meldingsplicht dient in te gaan, kan ik deze toevoeging niet gebruiken, omdat voor de meldingsplicht zo min mogelijk onzeker. heden in de omschrijving der fasen ingebouwd moeten worden.

Wanneer belanghebbenden hun medewerking hebben opgezegd is dat een feitelijk, makkelijk hanteerbaar gegeven; de toegevoegde zinsnede roept weer vragen op, waarvan de antwoorden in de tweede fase thuis horen.

Wanneer belanghebbenden hun medewerking opzeggen, dient de vraag of ze vervangen kunnen worden beantwoord te zijn; zolang dat nog in onderzoek is, dient de derde fase niet in te treden.

\section{Vier situaties}

Dit heeft tot gevolg, dat ik voor de bepaling van het tijdstip van de meldingsplicht niet zeven situaties onderscheid - zoals de meningsuiting - maar de navolgende vier:

beoordeling vooruitzichten:

- door bestuurders

- door accountant

\begin{tabular}{l}
$1 \quad 2 \quad 3 \quad 4$ \\
\hline
\end{tabular}

$\begin{array}{llll}+ & + & 0 & - \\ + & 0 & 0 & -\end{array}$

\section{Wanneer meldingsplicht}

Wanneer zowel bestuur als accountant van oordeel zijn, dat het bedrijf zich nog bevindt in de situatie welke hierboven werd aangeduid met het + teken, dienen de als gunstig beoordeelde perspectieven te worden afgewacht; dus geen mel. dingsplicht.

Indien naar het oordeel van de accountant naar aanleiding van een door hem ingesteld onderzoek de tweede fase (teken 0 ) is aangebroken, zal deze van "de ernstige onzekerheid omtrent de continuïteit" dienen te doen blijken in zijn verslag en in zijn verklaring.

Zodra zulks geschiedt zal in mijn voorstel de meldingsplicht voor de bestuur. 
ders ontstaan, ook al zijn deze zelf van mening, dat de situatie (nog) niet zo erns. tig is.

Zoals de toelichting op de balans een uiteenzetting dient te geven van de grondslagen waarop de waardering van de activa en passiva en de bepaling van het resultaat berusten en een wijziging in deze grondslagen uitdrukkelijk in de toelichting dient te worden vermeld (art. 311 B.W.), zo ook dient in dezelfde toelichting een waardering omtrent de continuilteit te worden uitgesproken en het moment aangegeven te worden waarop de fase met het 0.teken is aangebroken.

\section{Meldingsplicht na plotselinge débacle}

In het voorafgaande ben ik ervan uitgegaan, dat de verliesgevende situatie geleidelijk ontstaat en dat de accountant het bedrijfsbeeld bij normale uitoefe. ning van zijn werkzaamheden kan volgen.

Indien het débacle zich in enkele dagen voltrekt door oorzaken welke niet voorzienbaar waren (b.v. annulering van grote order, waarvoor geen vervan ging) zal de meldingsplicht in de meeste gevallen vergezeld dienen te gaan van een verzoek tot het verlenen van een surséance van betaling, al of niet ver. gezeld van een aanbod aan crediteuren, of tot failliet verklaring met verzoek tot benoeming van een bewindvoerder c.q. curator, in stede van een rappor. teur.

\section{Reactie accountants}

Omdat ik de wettelijke invoering van een vóó-fase een voor het bedrijfsleven belangrijke zaak vind, zou ik het op prijs stellen van de zijde van de registerac. countants hun mening te vernemen over de practische uitvoerbaarheid van een meldingsplicht en eventueel andere suggesties te ontvangen over het tijdstip, waarop een meldingsplicht dient te ontstaan. 